\title{
The ASHS Outstanding Fruit Cultivar Award: A 25-year Retrospective
}

\author{
Gayle M. Volk ${ }^{1}$ \\ U.S. Department of Agriculture-Agricultural Research Service, National Center for Genetic Resources \\ Preservation, 1111 S Mason Street, Fort Collins, CO 80521
}

James W. Olmstead

University of Florida-IFAS, Horticultural Sciences Department, Gainesville, FL 32611

Chad E. Finn

U.S. Department of Agriculture-Agricultural Research Service, Horticultural Crops Research Unit, 3420 NW Orchard Avenue, Corvallis, OR 97330

Jules Janick

Horticulture and Landscape Architecture, Purdue University, West Lafayette, IN 47907-2010

Additional index words. fruit industry, horticulture, plant breeding, pomology

\begin{abstract}
The Outstanding Fruit Cultivar Award is a medal presented annually by the Fruit Breeding Working Group of the American Society for Horticultural Science (ASHS) for noteworthy new fruits released over the previous 35 years. Since 1987, 38 cultivars have been recognized with medals presented at the Annual Conference of the Society. The awards celebrate the progress achieved by fruit breeders and their contributions to the world's fruit industry.
\end{abstract}

The world's fruit industry is based on distinct clones that have uniquely desirable horticultural characteristics. The genetic improvement of fruits known as fruit breeding in its broadest sense has an ancient tradition that dates back to the domestication process of the Neolithic and Bronze Age, $\approx 8,000$ to 10,000 years ago. Genetic improvement was achieved by selection, first from natural seedling populations and then from seedlings that occurred naturally in growers' fields with desirable genotypes fixed by vegetative propagation. In the middle of the 19th century, the English horticulturist Thomas Andrew Knight (1759-1838) initiated the science of fruit breeding by a combination of deliberate hybridization followed by selection and testing. Conventional fruit breeding is based on continuous selection of superior phenotypes from genetically variable populations using cycles of hybridization and selection and including special techniques such as mutation induction, interspecific hybridization, and backcross breeding. Recently, biotechnological techniques have been used including in vitro propagation, embryo rescue, protoplast fusion, marker-assisted selection, and transgenesis. The creation of new distinct cultivars as a result of the breeder's art has had an enormous influence on pomology and horticulture. Trait improvements have been associated

Received for publication 30 May 2012. Accepted for publication 25 Oct. 2012.

We thank the following colleagues for their helpful contributions to the text in this article: James Ballington, Duane Bartholomew, Tom Beckman, Susan Brown, William Castle, John Clark, William Cline, Fred Gmitter, Bruce Lampinen, Jim Luby, Paul Lyrene, Patrick Moore, Mike Neff, Dick Okie, David Ramming, Doug Shaw, Wayne Sherman, Tommy Thompson, and Nicholi Vorsa.

${ }^{1}$ To whom reprint requests should be addressed; e-mail Gayle.Volk@ars.usda.gov. with characters that are beneficial to consumers such as the improvement of edible quality and appearance and to growers, packers, and processors such as resistance to diseases and pests, increased yield, and postharvest quality.

\section{The Award and Medallion}

In 1976, Dr. Jules Janick, Dr. James Moore, and chapter authors assigned their royalties from Advances in Fruit Breeding (Janick and Moore, 1974) to the ASHS with the stipulation that the funds be used to promote fruit breeding. In 1983, the royalties for the companion volume Methods in Fruit Breeding (Moore and Janick, 1983) were added to the fund. In 1986, the ASHS Awards Committee approved an "Outstanding Fruit Cultivar Award," to be administered by the Fruit Breeding Working Group with expenses paid by the royalties' fund. The first award was made in 1987.

The Outstanding Cultivar Award was intended to honor the fruit cultivar. For the nomination process, the nominator submits information about the cultivar including: 1) brief history and development; 2) significance and impact of the cultivar; 3 ) names of individual associated with the cultivar; and 4) supporting letters. The award selection committee is composed of the officers of the ASHS Fruit Breeding Working Group and is coordinated by the past chair. The window to receive the award is 35 years from release. In some years, more than one award has been issued.

The Outstanding Cultivar Award medallion is based on a 1510 woodcut by Albrecht Dürer of Adam and Eve (Fig. 1A) that was modified to adorn the cover of Advances in Fruit Breeding (Fig. 1B). The companion Dürer woodcut was used for the cover of the Methods in Fruit Breeding (Fig. 1C; Janick and Moore, 1974; Moore and Janick, 1983). The medallion was designed by Janick and arrangements for its casting were made by Dr. Wayne Sherman. The obverse side of the medallion contains the image of Adam and Eve holding an apple with the words FOR GENETIC IMPROVEMENT in raised letters on the edge (Fig. 1D). The reverse side of the medallion contains the biblical phrase from Isaiah: "The Fruit of the Land Shall be the Pride and Glory. Is. 4:2 RSV" in the upper portion and the phrase "ASHS FRUIT BREEDING" on the lower edge. Space was left to engrave the name of the cultivar and the names of people associated with its breeding or release.

\section{Recipients and Impact}

The list of cultivar recipients and breeders associated with the cultivar's development from 1987 to 2012 is shown in Table 1 and the cultivars are depicted in Figure 2. A more detailed description of each awarded cultivar is listed below. We have made every effort to present a complete list of cultivar recipients for this 25th anniversary, and honor those who had a major role in developing these cultivars. However, some records of the Fruit Breeding Working Group have been lost over the years, and the authors deeply regret any omissions from this publication. If you are aware of an error or omission, we would greatly appreciate your information.

\section{Apple}

'Empire' Apple (1987) R. Way, A.J. Heinicke, L. Klein, J. Einsett, and K. Livermore. Seeds from the cross between 'McIntosh' and 'Red Delicious' that resulted in the 'Empire' apple were harvested in 1945 and planted in 1947 at the New York State Agricultural Experiment Station in 

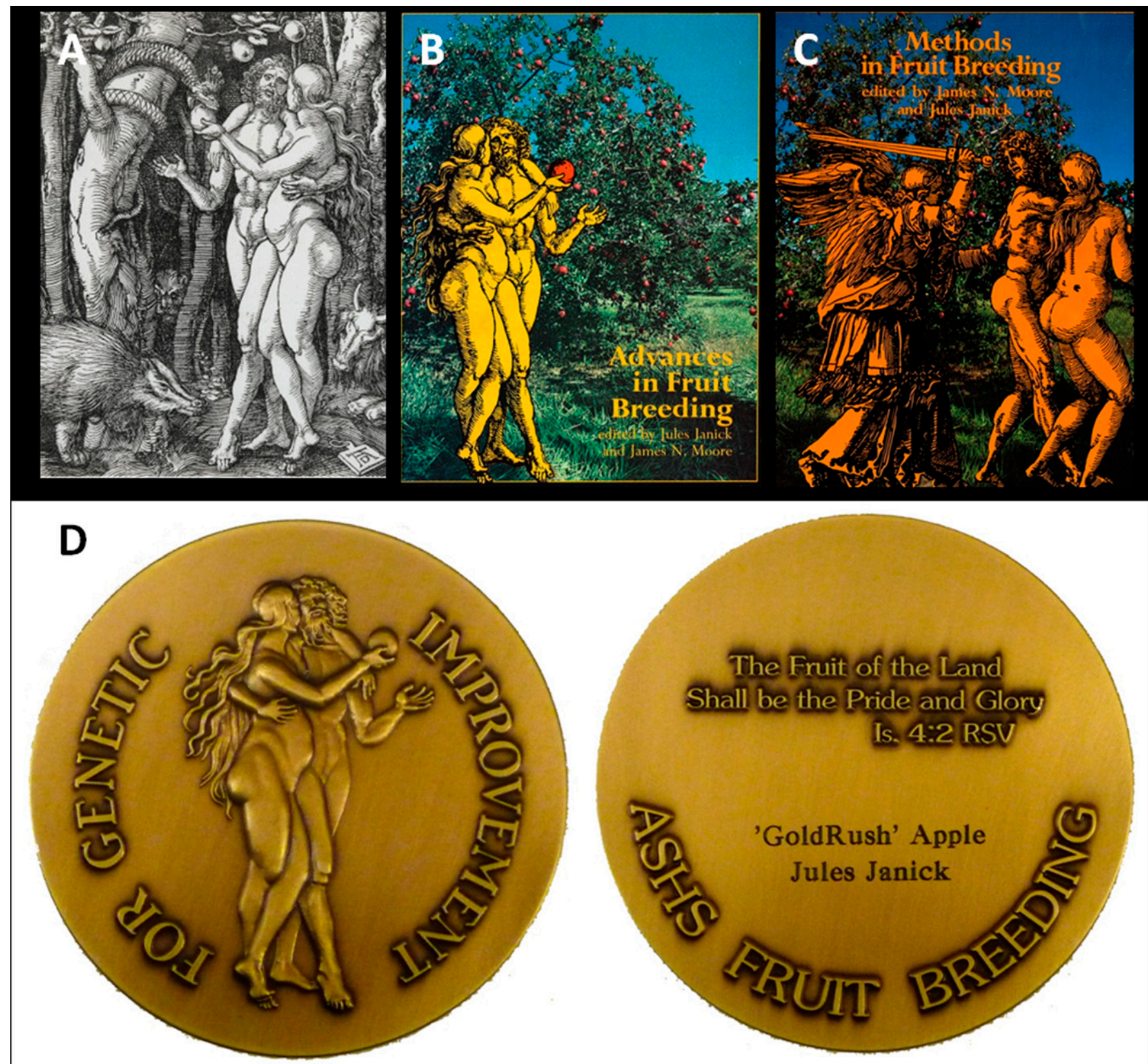

Fig. 1. (A) Image of the original 1510 woodcut by Albrecht Dürer of Adam and Eve; (B) cover of the Advances in Fruit Breeding textbook; (C) cover of the Methods in Fruit Breeding textbook; (D) Outstanding Cultivar Award medallion for 'GoldRush' apple.

Geneva, NY. 'Empire' was tested as N.Y. 45500-5 and was released in 1966 by pomologist Roger Way (McCandless, 1996).

'Empire' apples are crunchy, juicy, and sweet, with crisp, creamy white flesh. 'Empire' fruit has better coloration and resistance to preharvest drop than 'McIntosh' with similar flavor and aromatics. It is productive and has low susceptibility to fireblight. In 2009, the United States produced 6.6 million bushels of 'Empire' and it is the primary export apple in New York State.

'GoldRush' Apple (2011) J.A. Crosby, J. Janick, J.C. Goffreda, and S.S. Korban. 'GoldRush' was released in 1994 by the cooperative Purdue-Rutgers-Illinois (PRI) apple breeding program and derives from a cross of 'Golden Delicious' as the seed parent and Co-op 17 (PRI 1689-100) as the pollen parent. 'GoldRush', a late-maturing, scabresistant apple with excellent fruit quality and long storage life, was truly a breakthrough cultivar (Crosby et al., 1994). Its name reflects its "old-gold" color combined with a "rush" of flavor. Flavor is spicy with a full and complex flavor. 'GoldRush' has been consistently classified as the best tasting apple each year in Purdue, University of Illinois, and other evaluations during the winter and spring. The texture is crisp and maintains an exceptional crunchy mouth feel for its entire storage life without off-flavors. The tree is being widely planted in the United States and Europe and is marketed in France as 'Delisdor'. 'GoldRush' is the state fruit of Illinois and, in recent years, has become a highly valuable cultivar for developing genomics resources for Rosaceae as well as for mining the apple genome.

'Honeycrisp' Apple (2007) J.J. Luby and D.S. Bedford. 'Honeycrisp' apple has consumer name recognition for its very juicy and crisp texture and sweet but slightly tart flavor. 'Honeycrisp' resulted from a cross made in 1960 at the University of Minnesota Horticultural Research Center near Excelsior, MN. The seedling tree was planted in 1962 and selected in 1974. The University of Minnesota obtained a U.S. Plant Patent for 'Honeycrisp' in Mar. 1990, and it was introduced in 1991. In the late 2000s, over a million trees a year were being planted in the United States, and by 2011, over five million bushels of 'Honeycrisp' fruit were produced 
Table 1. Outstanding Fruit Cultivar Awards, 1987 to 2012.

\begin{tabular}{|c|c|c|}
\hline $\mathrm{Yr}$ & Cultivar & Recipients \\
\hline 1987 & 'Earliglow' strawberry & D.H. Scott, A.D. Draper; USDA, ARS, Beltsville, MD \\
\hline 1987 & 'Empire' apple & $\begin{array}{l}\text { R. Way, A.J. Heinicke, L. Klein, J. Einsett, K. Livermore; } \\
\text { New York State Agr. Expt. Sta., Geneva, NY }\end{array}$ \\
\hline 1988 & 'Jonagold'apple & $\begin{array}{l}\text { R. Way, H. Bennett, L. Klein, J. Einset, K. Livermore; } \\
\text { New York State Agricultural Experiment Station, } \\
\text { Geneva, NY }\end{array}$ \\
\hline 1989 & 'Chandler' strawberry & $\begin{array}{l}\text { R.S. Bringhurst, V. Voth; Univ. of California-Davis and } \\
\text { Irvine, CA }\end{array}$ \\
\hline 1989 & 'Flame Seedless' table grape & J.H. Weinberger, F. Harmon; USDA-ARS, Fresno, CA \\
\hline
\end{tabular}

1990 'Cardinal' strawberry

1990 'Springcrest' peach

1991 'Fantasia' nectarine

1991 'Flordaprince' peach

1992 'Friar' plum

1992 'Meeker' red raspberry

1993 'Sunburst' tangerine

1994 'Chandler' walnut

1997 'Swingle' citrumelo, citrus rootstock

1998 'Harvester' peach

1998 'Redglobe' table grape

1999 'Sharpblue' southern highbush blueberry

2000 'Rainbow' papaya

2000 'SunUp' papaya

2001 'Chester Thornless' blackberry

2002 'Camarosa' strawberry

2002 'Prima' apple

2003 'Pawnee' Pecan

2004 'Crimson Seedless' table grape

2004 'Duke' Blueberry

2004 'Heritage' red raspberry

2004 'Tulameen' red raspberry

2005 'Autumn Bliss' red raspberry

2005 'O'Neal' blueberry

2006 'BY520-9' Guardian ${ }^{\circledR}$, peach rootstock

2006 'Navaho' blackberry

2007 'Honeycrisp' apple
J.N. Moore, H.L. Bowden, W.A. Sistrunk; Univ. of Arkansas, Fayetteville, AR

V.E. Prince, J.H. Weinberger; USDA-ARS, Fresno, CA

J.H. Weinberger; USDA-ARS, Fresno, CA

W.B. Sherman, P.M. Lyrene, R.H. Sharpe, J.A. Mortensen; Univ. of Florida, Gainesville, FL

J.H. Weinberger; USDA-ARS, Fresno, CA

C.D. Schwartze; Washington State University, Puyallup, WA

C.J. Hearn; USDA-ARS, Orlando, FL

H. Ford, G. Serr; Univ. of California-Davis

W.T. Swingle, E.O. Olson, D. Hutchison, H. Wutscher; USDA-ARS-USHRL, Orlando, FL

J.C. Taylor and P.L. Hawthorne, Louisiana State Univ., Calhoun, LA

H.P. Olmo and A. Koyama, Univ. of California-Davis

R.H. Sharpe, W.B. Sherman; Univ. of Florida,

Gainesville, FL

D. Gonsalves, M. Fitch, R. Manshardt; Cornell Univ. and Univ. of Hawaii

D. Gonsalves, M. Fitch, R. Manshardt; Cornell Univ., Ithaca, NY, and Univ. of Hawaii, Honolulu, HI

J. Hull, G.J. Galletta, J.L. Maas; USDA-ARS, Beltsville, MD

V. Voth, R. Bringhurst, D. Shaw; Univ. of California, Davis

D.F. Dayton, J.B. Mowry, L.F. Hough, Catherine H. Bailey, E.B. Williams, Jules Janick, F.H. Emerson; Univ. of Illinois, Champaign-Urbana, IL, Rutgers Univ.,

New Brunswick, NJ, and Purdue Univ., W. Lafayette, IN

T. Thompson and L. Romberg; USDA-ARS, Somerville, TX

\section{Ramming, R. Tarailo; USDA-ARS, Fresno, CA}

A. Draper, G.J. Galletta, G. Jelenkovic, N. Vorsa, S. 'Duke' Galletta; USDA-ARS, Beltsville, MD, and Rutgers Univ., Chatsworth, NJ

G.L. Slate, D.K. Ourecky; Cornell Univ., New York State Agricultural Experiment Station, Geneva, NY

H.A. Daubeny; Agriculture and Agri-Foods Canada, Vancouver, British Columbia, Canada

E. Keep, V. Knight; Horticulture Research International, E. Malling, U.K.

J. Ballington, A. Draper; North Carolina State Univ., Raleigh, NC, and USDA-ARS, Beltsville, MD

T. Beckman, B. Newall Jr., A. Nyczepir, D. Okie, G. Reighard, E. Zehr; USDA-ARS, Byron, GA, and Clemson University, Clemson, SC

J.N. Moore, J.R. Clark; Univ. of Arkansas, Fayetteville, AR

J.J. Luby, D.S. Bedford; Univ. of Minnesota, St. Paul, MN
Very early ripening, outstanding flavor, and attractive berries with resistance to red stele root rot; standard early for eastern United States for decades

McIntosh-type flavor with better coloration and less resistant to drop; primary export apple of New York

High-quality triploid that saved the European fruit industry where it became the leading apple cultivar

Tender, juicy texture; dominated fresh market production in southern California in 1990s

Second most important seedless grape produced in the United States with large clusters of sweet, medium-large red grapes

Highly productive cultivar for lower Midwest, South, and upper South in the matted row cultivation system

Firm, very early peach that once dominated the California market

High-quality, firm nectarine; was once the most important nectarine in California and remains widely planted worldwide

First commercial peach for subtropics with exceptional fruit size, attractiveness, and sugar

One of the first commercially accepted black skin plums

Excellent processing fruit that retains its brightness and flavor

Attractive with long shelf life, once a very significant fresh fruit cultivar

Highly productive with light-colored kernels that store well

Virus and root rot tolerant rootstock for grapefruit and sweet orange production in Florida

High-quality, early-maturing freestone peach cultivar widely adapted to southern growing areas

Round, large firm, and juicy table grapes with seeds

One of the first low-chill southern highbush blueberry cultivars; vigorous with high fruit quality

Yellow-orange flesh with resistance to papaya ringspot virus; transgenic

Red-orange flesh, soft and juicy flesh with resistance to papaya ringspot virus; transgenic

Thornless semierect plant with large production of uniform, firm fruit

Short-day cultivar with large, firm and deep red fruit; farm-gate value of $\$ 1.5$ billion at its peak

The first scab-resistant release containing the $V_{f}$ gene from Malus floribunda 821

Early nut maturity, high quality, and high resistance to yellow aphid complex; most popular pecan cultivar worldwide

Number one California late-ripening, red seedless grape

Most popular cultivar in the world at least until early 2000s; very high quality for fresh market; self-pollinating with high yields of early, firm fruit

High-yielding, reliably productive, and good shippable fruit quality with some disease resistance

Bright, glossy, firm medium red-colored fruit with excellent flavor that can be shipped internationally

High fruit quality produced on a very early ripening primocane plant

Very early ripening, intermediate chill requirement, and adaptable to amended soils

Patented rootstock that provides resistance to peach tree short life disease

First erect-caned thornless blackberry with excellent shipping qualities

"Explosively crisp" apple with high consumer acceptability, changing the marketing of apples to consumers in the United States 
Table 1. (Continued) Outstanding Fruit Cultivar Awards, 1987 to 2012.

\begin{tabular}{|c|c|c|c|}
\hline$\overline{\mathrm{Yr}}$ & Cultivar & Recipients & Remarks \\
\hline 2009 & 'Noble' muscadine grape & $\begin{array}{l}\text { W.B. Nesbitt, D.E Carroll, Jr., V.H. Underwood; } \\
\text { North Carolina State Univ. Raleigh, NC }\end{array}$ & $\begin{array}{l}\text { Most widely grown black-fruited muscadine in the } \\
\text { United States; stable pigmentation for winemaking } \\
\text { and cold-hardy }\end{array}$ \\
\hline 2010 & 'Tupy’ blackberry & $\begin{array}{l}\text { Alverides Machado dos Santos; EMBRAPA Clima } \\
\text { Temperado, Pelotas, RS, Brazil }\end{array}$ & $\begin{array}{l}\text { Most important blackberry cultivar in the world; } \\
\text { grown almost exclusively in Mexico's central } \\
\text { highlands }\end{array}$ \\
\hline 2012 & 'Black Diamond' blackberry & $\begin{array}{l}\text { C. Finn, R.R. Martin, B.C. Strik, B.M. Yorgey, M. Qian, } \\
\text { H.K. Hall; USDA-ARS, HCRL, Corvallis, OR, Oregon } \\
\text { State Univ., New Zealand HortResearch Inc. }\end{array}$ & $\begin{array}{l}\text { Thornless, high-yielding, machine-harvestable with } \\
\text { good fruit quality }\end{array}$ \\
\hline 2012 & 'Sweetheart' cherry & $\begin{array}{l}\text { D. Lane; Agriculture and Agri-Foods Canada, Summerland, } \\
\text { British Columbia, Canada }\end{array}$ & Late-maturing, self-fertile with large, firm fruit \\
\hline
\end{tabular}

with a value estimated to be $\$ 250$ million. International Plant Variety Rights and licenses for 'Honeycrisp' have been obtained by the University of Minnesota for production in Canada, Germany, South Africa, New Zealand, and Chile. 'Honeycrisp' was named one of the "25 Innovations that Changed the World" by the Association of University Technology Managers in 2006, recognizing it as one of the most important inventions to come from university research. In 2006, the Minnesota state legislature passed a bill declaring 'Honeycrisp' apple the state fruit of Minnesota.

'Jonagold' Apple (1988) R. Way, H. Bennett, L. Klein, J. Einsett, and K. Livermore. 'Jonagold' is a triploid apple cultivar known for its high eating quality. 'Jonagold' resulted from a cross made in 1943 between 'Golden Delicious' and 'Jonathan' made at the New York State Agricultural Experiment Station in Geneva, NY. It was selected in 1953, tested as N.Y. 43013-1, and officially released in 1968 by Roger Way (Way and Brown, 1991). Currently, the United States produces 2.5 million bushels per year, primarily in Washington State, and Belgium is the largest producer in Europe. In 1989, 'Jonagold' was rated as the number one dessert apple in an informal survey of apple breeders and experts (Norton, 1989). Demand for 'Jonagold' soared with its use in Stella Cidre (Belgian), which only uses this cultivar for its cider production.

'Prima' Apple (2002) D.F. Dayton, J.B. Mowry, L.F. Hough, Catherine H. Bailey, E.B. Williams, J. Janick, and F.H. Emerson. 'Prima' was released in 1970, the first release from the cooperative program involving Purdue University, Rutgers University, the State University of New Jersey, and the University of Illinois designed to breed scab-resistant apples. The apple was derived from a cross between PRI 14-510, a seedling grown at the University of Illinois derived from Malus floribunda 821 as the seed parent carrying the $V f$ gene for resistance to apple scab, with pollen from a New Jersey seedling, NJ 123249. 'Prima' was tested as $1225-100$ and was formerly known by the name of Co-op 2 (Dayton et al., 1970). It is an early fall red apple with good flavor that was widely planted and tested worldwide. The seedling was screened for scab resistance at Purdue University and selected at the University of Illinois. 'Prima' has been used in breeding, was one of the first apples to have its genome sequenced, and is used in mapping studies and for cloning genes of many important horticultural traits.

\section{Blackberry}

'Black Diamond' Blackberry (2012) C.E. Finn, R.R. Martin, B.C. Strik, B.M. Yorgey, M. Qian, and H.K. Hall. 'Black Diamond' was released by the U.S. Department of Agriculture-Agricultural Research Service (USDA-ARS) in 2005, resulting from a collaboration between the USDA, Oregon State University, and New Zealand HortResearch Inc. Originally labeled as 'NZ 9128R', it was a seedling from a cross between 'Kotata' and a selection from the New Zealand blackberry breeding program. In the Oregon field trials, it was immediately selected for its thornless, high-yielding, machine-harvestable, and good fruit quality traits. By 2004 significant grower trials were fruiting and very quickly after it was released, it became the number one cultivar planted in the Pacific Northwest, and it will soon replace 'Marion' as the number one cultivar in the ground.

'Chester Thornless' Blackberry (2001) J.W. Hull, G.J. Galletta, and J.L. Maas. 'Chester Thornless' blackberry was released in 1985 by the USDA-ARS in Beltsville, MD, in cooperation with the Illinois Agricultural Experiment Station, The Ohio Agricultural Research and Development Center, and the Maryland Agricultural Experiment Station. The original cross of SIUS $47 \times$ 'Thornfree' was made in 1968 by J.W. Hull in Carbondale, IL. 'Chester Thornless' has been exceptional as the first semierect blackberry with very large production (up to $34 \mathrm{mt} \cdot \mathrm{ha}^{-1}$ ) of uniform, firm fruit that are well-suited for fresh market shipping in the late season. It became the world industry standard in the 1990s for late-season production and remains one of the most widely planted cultivars in temperate regions. 'Chester Thornless' has only fair flavor with large seeds that are increasingly seen as a detriment as newer, higher quality cultivars are released. However, the advent of tunnel production in many areas of the world has extended the impact of 'Chester Thornless'.

'Navaho' Blackberry (2006) J.N. Moore and J.R. Clark. 'Navaho', released by J.N. Moore and J.R. Clark in 1989, was the first thornless blackberry from the University of Arkansas and the first erect-caned thornless blackberry ever developed. 'Navaho', tested as Ark. 1172, resulted from a cross between Ark. 583 and Ark. 631, both heterozygous for the thornless characteristic (Moore and Clark, 2000). 'Navaho' is likely the best shipping blackberry available today. It is of exceptional quality with high soluble solids. During its patent lifetime, 1.7 million 'Navaho' plants were sold, and it has continued to be planted after patent expiration. 'Navaho' has been marketed in Europe for many years, mainly in the garden market and some local market production. Interestingly, on imminent release of 'Navaho', orange rust was discovered on it in one test plot in eastcentral Arkansas. This created concern for its release because orange rust resistance was obligate for Arkansas releases, and it was thought that Arkansas material was well screened for resistance. Release proceeded, however, and this was the right call because 'Navaho' has had a very substantial impact in the emerging blackberry industry in the last 15 years. Although orange rust has been observed in plantings, it is seldom a serious problem.

'Tupy' Blackberry (2010) Alverides Machado dos Santos. 'Tupy' blackberry, released by Alverides Machado dos Santos with EMBRAPA Clima Temperado (Pelotas, Brazil), was originally described as a hybrid of 'Uruguayan' or a wild trailing blackberry from Uruguay with 'Comanche' erect blackberry. There are no native wild blackberries in Uruguay, and the maternal parent is presumed to be either 'Boysen' or a 'Boysen' seedling. The cross was made in 1982 and 


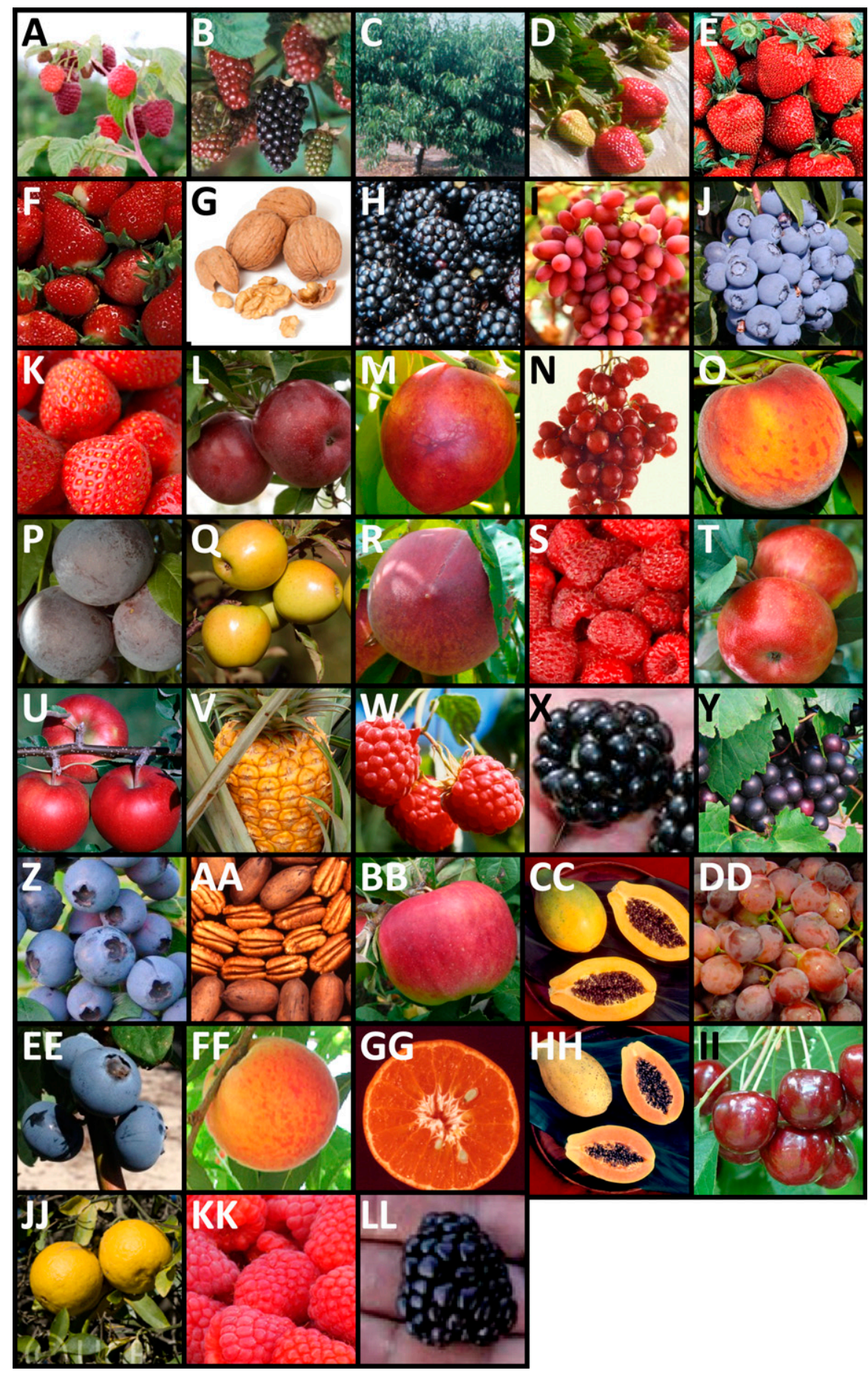

Fig. 2. Medal recipients and source of image. (A) 'Autumn Bliss' red raspberry (Chad Finn, USDA-ARS); (B) 'Black Diamond' blackberry (Chad Finn, USDA-ARS); (C) 'BY520-9' Guardian ${ }^{\circledR}$ peach rootstock (T.G. Beckman, USDA-ARS); (D) 'Camarosa' strawberry (Doug Shaw, University of California, Davis); (E) 'Cardinal' strawberry (John Clark, University of Arkansas); (F) 'Chandler' strawberry (USDA Image Gallery); (G) 'Chandler' walnut (Lori Eason, Gold River Orchards); (H) 'Chester Thornless' blackberry (Chad Finn, USDA-ARS); (I) 'Crimson Seedless' grape (USDA Image Gallery); (J) ‘Duke' blueberry (Bernadine Strik, Oregon State University); (K) 'Earliglow' strawberry (Chad Finn, USDA-ARS); (L) 'Empire' apple (Susan Brown, Cornell University); (M) 'Fantasia' nectarine (Desmond Layne, Clemson University); (N) 'Flame Seedless' grape (USDA Image Gallery); (O) 'Flordaprince' peach (Mercy Olmstead, University of Florida); (P) 'Friar' plum (Robert Woolley, Dave Wilson Nursery); (Q) ‘GoldRush' apple (Jules Janick, Purdue University); (R) ‘Harvester' peach (Desmond Layne, Clemson University); (S) 'Heritage' red raspberry (Chad Finn, USDA-ARS); (T) 'Honeycrisp' apple (David Hansen, University of Minnesota); (U) 'Jonagold' apple (Susan Brown, Cornell University); (V) 'MD-2' pineapple (Jody B. Bartholomew, Honolulu, HI); (W) 'Meeker' red raspberry (Patrick Moore, Washington State University); (X) 'Navaho' blackberry (John Clark, University of Arkansas); (Y) 'Noble' muscadine grape (William Cline, North Carolina State University); (Z) 'O'Neal' blueberry (Fall Creek Farm and Nursery); (AA) 'Pawnee' pecan, (USDAARS Image Gallery); (BB) 'Prima' apple, (Jules Janick, Purdue University); (CC) 'Rainbow' papaya,
(Richard Manshardt, University of Hawaii, Manoa); (DD) 'Redglobe' grape (copyright-free image); (EE) 'Sharpblue' blueberry (James Olmstead, University of Florida); (FF) 'Springcrest' peach (Dave Wilson Nursery); (GG) 'Sunburst' tangerine (Greg McCollum, USDA-ARS); (HH) 'SunUp' papaya (Richard Manshardt, University of Hawaii, Manoa); (II) 'Sweetheart' cherry (Neal Manly, Willow Drive Nursery); (JJ) 'Swingle' citrumelo citrus rootstock (University of California, Riverside Citrus Variety Collection); (KK) 'Tulameen' red raspberry (Chaim Kempler, Agriculture and Agri-Food Canada); (LL) 'Tupy' blackberry (John Clark, University of Arkansas).

the progeny were grown at the EMBRAPA station in Pelotas. In the mid-1990s, growers with ITALBRAZ exported the fruit to European markets and they were well accepted. 'Tupy' was registered (No. 20,339) with the Brazilian Ministry of Agriculture on 11 Jan. 2006, although it had already been called 'Tupy' in the trade for many years. Because of this success, 'Tupy' was taken to Mexico where it was tested and established. Mexican blackberries currently account for over $85 \%$ of all USDA-reported fresh blackberry shipments, and nearly all are of the Tupy cultivar. The fruits are firm, longer than wide, dark, and large (7-9 g) but not giant. 'Tupy' was also well adapted to a production system where defoliation, drought, and growth regulators are used to bring on the fruiting at targeted times. Although most of the production is geared toward the United States, Canada, and Europe off season, these tools allow fresh production of 'Tupy' from October until May.

\section{Blueberry}

'Duke' Blueberry (2004) A.D. Draper, G.J. Galletta, G. Jelenkovic, N. Vorsa, and S. 'Duke' Galletta. 'Duke' highbush blueberry was jointly released in 1987 by the cooperative blueberry breeding program of the USDA and New Jersey Agricultural Experiment Station (Draper et al., 1987). 'Duke' was evaluated as G-354 and resulted from a cross between G-100 ('Ivanhoe' $\times$ 'Earliblue') and 192-8 (E-30 × E-11) made in the mid-1960s by Arlen Draper. 'Duke' has consistent high yields and good fruit set after self-pollination. Fruit are early and firm with a long storage life. 'Duke' became an industry standard in the 1990s and was probably the most important cultivar in the world by the early 2000s. Arlen Draper was hesitant to release 'Duke' because he did not think it had enough flavor. However, 'Duke' had two characteristics that made it stand out. It had a "pop" when you ate it that made it pleasurable to eat, and it held whatever flavor it had very well in storage while other cultivars declined more precipitously in flavor quality. It is widely planted in the United States and in South America. 'Duke' is named in honor of S. Arthur (Duke) Galletta from the Atlantic Blueberry Co. (Hammonton, $\mathrm{NJ}$ ), an early blueberry pioneer and a long time 
supporter of USDA-ARS blueberry breeding efforts.

'O'Neal' Blueberry (2005) J.R. Ballington and A.D. Draper. 'O'Neal' was released in 1987 as a very early-ripening southern highbush cultivar for southeastern North Carolina. Tested as NC 1688, it resulted from a cross between 'Wolcott' and FL 64-15 made in Beltsville, MD, and was selected in Castle Hayne, NC, in 1972 (Ballington et al., 1990). Quickly recognized as unique for its ripening date, adaptability to soils, intermediate chill requirement and good fruit quality, 'O'Neal' has been used in many new production areas and countries as a "test" cultivar by entrepreneurs seeking to develop new markets. As blueberry production extended into low chill areas, 'O'Neal' was the predominant cultivar planted and in the late 1990s was among the top cultivars being planted worldwide. It is grown successfully on amended soils and remains a leading cultivar in the southern United States and South America. 'O'Neal' has an open bush habit and loose clusters, so although it was initially released for early hand harvest, it is also well adapted for mechanical harvest, and later pickings are commonly machine-harvested for the fresh or processing markets. 'O'Neal' has proven to be an outstanding parent in the development of newer southern highbush cultivars, including 'Star' and 'New Hanover'.

'Sharpblue' Southern Highbush Blueberry (1998) R.H. Sharpe and W.B. Sherman. 'Sharpblue' southern highbush blueberry was released by R.H. Sharpe and W.B. Sherman in 1976. 'Sharpblue' along with 'Flordablue' released the same year were the first low-chill southern highbush blueberry cultivars released (Lyrene and Sherman, 1992). 'Sharpblue' resulted from a cross between two selections, FL 61-5 and FL 62-4, made in 1964. 'Sharpblue' has a very low chilling requirement when grown in deciduous production systems but has the ability to flower and produce new leaves in good balance early in the spring, a characteristic that was difficult to select for in early southern highbush breeding efforts. 'Sharpblue' is vigorous with high fruit quality. However, the cultivar was originally intended for homeowner production as a result of a wet stem scar. In drier production areas, this was much less of a problem than anticipated. 'Sharpblue' is no longer commercially grown, but the low-chill areas of production that were opened by it have greatly contributed to the exponential expansion of blueberry production worldwide.

\section{Cherry}

'Sweetheart' Cherry (2012) D. Lane. 'Sweetheart' cherry originated from a cross between 'Van' and 'Newstar' made in 1975 at the Agriculture and Agri-Food Canada Research Center at Summerland, British Columbia, Canada. The seedling was first selected in 1982 and grower testing began in 1986. Named in 1994, 'Sweetheart' is late-maturing and self-fertile with large, firm fruits. It is also precocious and produces heavily. Exports from British Columbia exceeded \$15 million in 2005 and in 2012 it was the second most important cultivar in Washington State. 'Sweetheart' is also grown worldwide as a valuable variety in New Zealand, Tasmania, and Chile. 'Sweetheart' has also been an important parent in breeding programs, leading to a number of new cultivars that include 'Staccato', 'Sentennial', and 'Sovereign'.

\section{Citrus}

'Sunburst' Tangerine (1993) C.J. Hearn. 'Sunburst' was released in 1979 by C.J. Hearn after 18 years of development. 'Sunburst' was tested as 1-16-8 and resulted from a cross between 'Robinson' and 'Osceola' made in 1961 by P.C. Reece (Hearn, 1979). It is known for its attractive appearance, external color, good shipping qualities, and long shelf life. It has early to midseason maturity and a deep orange-red external color. 'Sunburst' is used primarily for fresh production but has been used for juice blending. When nominated for the Outstanding Fruit Cultivar Award, 'Sunburst' tangerine was a very significant fresh fruit cultivar in Florida. 'Sunburst' production and sales have declined over the past decade as a result of competition with seedless 'Clementine' fruit from other areas of the world. Currently, it is in second place behind 'Murcott' ('Honey tangerine') in Florida.

'Swingle' Citrumelo Citrus Rootstock (1997) W.T. Swingle, E.O. Olson, D. Hutchison, and $H$. Wutscher. 'Swingle' citrumelo resulted from a hybridization in 1907 between Citrus paradisi Macf. 'Duncan' grapefruit $\times$ Poncirus trifoliata (L.) Raf. 'Swingle' was tested as Citrumelo CPB 4475. It was formally released by the USDA-ARS U.S. Horticultural Research Laboratory in Orlando, FL, in 1974 and is a dwarfing rootstock with high productivity per unit of tree size (Hutchison, 1974). 'Swingle' is intermediate between "sour orange" and "rough lemon" rootstocks for cold-hardiness. 'Swingle' citrumelo rootstock is tolerant of Citrus tristeza virus and Phytophthora parasitica (root rot) for grapefruit and sweet orange production, thus making it one of the most highly used rootstocks in Florida.

\section{Grape}

'Crimson Seedless' Grape (2004) D. Ramming and R. Tarailo. 'Crimson Seedless' was the only late-ripening red seedless grape at the time of release by D. Ramming and R. Tarailo of the USDA-ARS, Parlier, CA. Tested as selection 102-26, 'Crimson Seedless' resulted from a cross between 'Emperor' and C33-199 (Dokoozlian et al., 1995). The cultivar was released in 1989, only nine years after its initial cross, but 66 years of prior breeding in the USDA Parlier grape breeding program were needed to build the background for this cultivar. 'Crimson Seedless' is the number one table grape cultivar grown in California. As a result of its consistent sweetness, it outsells white grape cultivars. As a result of its novel late maturity niche, no large production trials were performed. In 2009 , almost 20 million $19-1 b$ boxes were produced in the United States with an annual value of nearly $\$ 300$ million. 'Crimson Seedless' also has an international impact with production in Chile, Australia, China, South Africa, Egypt, Israel, Italy, Brazil, and Peru.

'Flame Seedless' Grape (1989) J. Weinberger and F. Harmon. 'Flame Seedless' grape was bred by J. Weinberger and F. Harmon of the USDA-ARS in Fresno, CA. It resulted from a cross made in 1961 that involved selections with 'Cardinal', 'Sultanina', 'Red Malaga', 'Tifafihi Ahmer', and 'Muscat of Alexandria' in their pedigree. 'Flame Seedless' was tested as selection 32137 and released in 1973 (Weinberger and Harmon, 1974). 'Flame Seedless' set the standard for seedless table grape quality, and it is currently the second most important seedless grape produced in the United States. It produces large clusters of medium-large red grapes with sweet flavor and a long shelf life. 'Flame Seedless' responds well to horticultural manipulations such as girdling and gibberellin treatments to increase size. Its texture is notable as very firm and crisp, but it is susceptible to Pierce's disease.

'Noble' Muscadine Grape (2009) W.B. Nesbitt, D.E. Carroll Jr., and V.H. Underwood. 'Noble' is the most widely grown blackfruited muscadine cultivar in the United States. It resulted from a cross between 'Thomas' and 'Tarheel' muscadine grapes made in 1946, was selected in 1951 by C.F. Williams, and released in 1972. 'Noble' was tested as NC 20-119 (Nesbitt et al., 1974). Within the muscadine-growing region of the southeastern United States, it is highly productive, self-fertile, and very disease-resistant. 'Noble' has stable pigments that retain their red color longer than other muscadines when used for winemaking or processing. 'Noble' has a wet picking scar when first ripe but detaches cleanly when fully ripe and is dull black in color. Rarely planted for commercial the fresh market or pick your own as a result of its small size, 'Noble' is still a common home cultivar attributable to its productivity. It is widely adapted within the southeastern United States and is resistant to black rot. 'Noble' is the most common muscadine wine grape in Florida while at the same time one of the most cold-hardy cultivars at the northern limit of production in North Carolina and into Virginia.

'Redglobe' Grape (1998) H.P. Olmo and A. Koyama. 'Redglobe' table grape resulted from a cross made in 1958 among the 'Red Emperor', 'Hunsia', and the 'Nocera' varieties of grapes. It was released by the University of California, Davis, in 1981. 'Redglobe' red grapes are round, large, firm, and juicy but also contain seeds. They grow in large fruited clusters and are very popular among consumers in Asia, the Middle East, and eastern Europe. Vines are vigorous and yields are high. For field production, they require long, warm growing seasons such as those in 
California or Australia. In cooler climates, 'Redglobe' grapes are produced in greenhouses.

\section{Nectarine}

'Fantasia' Nectarine (1991) J.H. Weinberger. 'Fantasia' nectarine was selected by J.H. Weinberger at the USDA-ARS, Fresno, CA, station in 1964. 'Fantasia' resulted from a cross between 'Gold King' and P101-24 (open-pollinated seedling of 'Red King') made in 1961. 'Fantasia' was tested as selection number F58-40 and was released by J.H. Weinberger in 1969 (Weinberger, 1970). 'Fantasia' is freestone with high fruit quality, good red color, and very firm texture. At its peak in the 1980s, 'Fantasia' was one of the most widely planted nectarines in California. 'Fantasia' has also been important as a source of the slow-ripening trait in nectarine (Ramming, 1991) and has the dubious honor of being the first Prunus cultivar to test positive for Plum pox potyvirus in Ontario, Canada (Thompson et al., 2001).

\section{Papaya}

'Rainbow' Papaya (2000) D. Gonsalves, M. Fitch, and R. Manshardt. 'Rainbow' is a gynodioecious hybrid cultivar developed to meet the demands of the papaya industry in Hawaii for an export quality fruit with the yellow-orange flesh color and resistance to Papaya ringspot virus (PRSV). Collaborating researchers at the University of Hawaii at Manoa, Cornell University, and the USDA used a combination of genetic engineering and conventional breeding techniques to achieve the goal. 'Rainbow' is an $\mathrm{F}_{1}$ hybrid produced by crossing Hawaii's standard export cultivar, Kapoho (yellow flesh, PRSVsusceptible), with 'SunUp' (red flesh, transgenic PRSV resistance). 'Rainbow' is highly productive and more widely adapted to microclimatic variation than its 'Kapoho' parent but somewhat more susceptible to Phytophthora fruit rot, stem canker, and root rot. 'Rainbow' has excellent transgenic resistance to PRSV with the superior quality and yellow flesh necessary for export. 'Rainbow' and its parent, 'SunUp', were the first genetically engineered tree fruit cultivars to reach commercial production and the first transgenic crop plants to be released by U.S. public institutions (1998). By 2009, plantings of 'Rainbow' accounted for $\approx 75 \%$ of commercial papaya crop area in Hawaii, in part as a result of their resistance to Phytophthora fruit rot, stem canker, and root rot.

'SunUp' Papaya (2000) D. Gonsalves, M. Fitch, and R. Manshardt. 'SunUp' papaya is a gynodioecious inbred line developed to meet the demands of Hawaii papaya growers for a high-quality cultivar with resistance to a devastating disease, PRSV. 'SunUp' was produced by collaborators at the University of Hawaii at Manoa, Cornell University, and USDA-ARS by inserting the coat protein gene from PRSV into 'Sunset', a gynodioecious inbred line with established commercial appeal. The genetic transformation was accomplished in 1989 in Geneva, NY, and tissue culture line 55-1 was regenerated in Hawaii and screened with PRSV in Geneva, NY. It was found to be resistant in the Geneva greenhouse in 1991 and in Hawaiian fields in 1993. Two generations of self-pollination resulted in fixing the transgene in a homozygous state, and the line was named 'SunUp' to differentiate its important virus resistance property from PRSV-susceptible 'Sunset'. Except for its high degree of resistance to Hawaiian strains of PRSV, 'SunUp' has characteristics identical to those of 'Sunset'. Fruits are high quality, but flesh texture is soft and juicy, making it less durable for export shipping. As a result of its susceptibility to Phytophthora fruit rot, stem canker, and root rot, 'SunUp' accounted for less than 5\% of commercial papaya crop area in Hawaii in 2009 .

\section{Peach}

BY520-9 Guardian ${ }^{\circledR}$ Peach Rootstock (2006) T. Beckman, B. Newall Jr., A. Nyczepir, D. Okie, G. Reighard, and E. Zehr. 'Guardian' (BY520-9) ${ }^{\circledR}$ peach seedling rootstock was cooperatively released in 1993 by the USDA-ARS Southeastern Fruit and Tree Nut Research Laboratory and Clemson University. Guardian ${ }^{\circledR}$ was selected from a cross between FV 235-4 and 'Nemaguard' made by John Weinberger (Beckman et al., 1997). To date, Guardian ${ }^{\circledR}$ has consistently demonstrated superior resistance to peach tree short life (PTSL), which before its release was the primary cause of premature peach tree mortality in the southeastern United States. Because of its clearly superior performance on PTSL-prone sites, Guardian ${ }^{\circledR}$ has displaced all other competing peach seedling rootstocks such as 'Lovell', 'Halford', and 'Nemaguard' in the southeastern U.S. peach industry. At this time it is estimated that $80 \%$ of the trees being planted by the southeastern U.S. peach industry are propagated on Guardian ${ }^{\circledR}$ and annual sales to licensed nurseries are well over one million seed (T. Beckman, personal communication). In 2001, Guardian ${ }^{\circledR}$ rootstock was granted U.S. Plant Variety Protection Patent No. 9400013, a first for a woody plant.

'Flordaprince' Peach (1991) W.B. Sherman, P.M. Lyrene, R.H. Sharpe, and J.A. Mortensen. 'Flordaprince' peach is a low-chill-requiring peach that was released in 1981 by W.B. Sherman, P.M. Lyrene, R.H. Sharpe, and J.A. Mortensen at the University of Florida. 'Flordaprince' resulted from a cross between Fla. 2-7 and Fla. 13-72 made in 1972 by Ralph Sharpe and was tested as Fla. 5-2 (Sherman et al., 1982). 'Flordaprince' was named in honor of Victor E. Prince, a USDA peach breeder in Fort Valley, GA, and long-time cooperator of the University of Florida program. 'Flordaprince' was the first commercial peach cultivar for the subtropics that had exceptional fruit size, attractiveness, and desirable sugar levels. Trees of 'Flordaprince' will fruit in Miami, FL, after most winters. 'Flordaprince' is no longer commercially grown in the United States, but worldwide, over 90,000 ha has been planted in Australia, Argentina, Egypt, Mexico, and Morocco.

'Harvester' Peach (1998) J.C. Taylor and P.L. Hawthorne. 'Harvester' peach is an earlymaturing, freestone peach developed for medium chill-requiring production areas. 'Harvester' resulted from a cross between 'Redskin' and 'Southern Glow' peaches made in 1960 and was selected by J.C. Taylor in 1964. 'Harvester' was tested as the selection number L61-2-42 at the Calhoun Research Station in Calhoun, LA, and was released in 1973 by the Louisiana Agricultural Experiment Station peach breeding program. The combination of earliness, freestone, consistent cropping and size, firmness for shipping, disease resistance, and attractive coloring has made 'Harvester' one of the most widely planted peaches in the southern United States (Graham, 1999).

'Springcrest' Peach (1990) V.E. Prince and J.H. Weinberger. 'Springcrest' peach is firm, attractive, very early, round, and has a high degree of red blush. 'Springcrest' resulted from a cross of FV89-14 $\times$ 'Springtime' made in 1958 by Victor E. Prince. It was tested as FV9-170 and released by the USDA-ARS in 1969 (Okie and Myers, 1991). Although developed and tested extensively in the Southeast, John Weinberger trialed the selection in California, and its performance there was instrumental in its eventual release. At one time, it was the major early peach in California, dominating the market for two decades. It was also the leading early cultivar in Italy, France, and other European as well as South American countries (Okie and Myers, 1991). It was the most widely grown peach since 'Redhaven', and it has been a major contributor to new cultivars as a parent or source of bud sports (Okie and Myers, 1991).

\section{Pecan}

'Pawnee' Pecan (2003) T. Thompson and L. Romberg. Tommy Thompson and L. Romberg of the USDA-ARS in College Station, TX, crossed 'Mohawk' $\times$ 'Starking Hardy Giant' in 1963 and selected 63-16125 from the progeny. This selection was released as 'Pawnee' in 1984 (Thompson and Grauke, 2000). 'Pawnee' has early nut maturity, high nut quality, and the highest resistance to yellow aphid complex known. It is the most popular pecan cultivar in the world, as measured by the number of trees planted. 'Pawnee' has a \$50 million farm gate value and $\$ 100$ million retail value. The release of this cultivar revolutionized the cultural practices of pecan production. It was discovered that all cultivars could be shaken during the growing season to thin nuts on overproducing trees. This allowed trees to be synchronized loadwise in terms of nut production capacity and allowed for adequate carbohydrate reserves for the trees to set nut crops in the next year (in contrast to biennial bearing).

\section{Plum}

'Friar' Plum (1992) J.H. Weinberger. 'Friar' plum was developed and released by 
John Weinberger at the USDA-ARS research station in Fresno, CA. 'Friar' was selected from a 'Gaviota' $\times$ 'Nubiana' cross made in 1957 and tested as F34-29. When 'Friar' was released in 1968, it was among the first blackskinned plum cultivars to find commercial success. It is large with a small pit, has fully black skin when ripe, with contrasting amber flesh color. The fruit is firm and stores well. At the peak of fresh plum production in California during the 1990s, 'Friar' was the most planted cultivar, and although total plum production has declined in more recent years, 'Friar' is still the second most widely produced cultivar in California (Hansen, 2012).

\section{Pineapple}

'MD-2' Pineapple (2009) D.F. William, T. Minagawa, and F. Bermudas. 'MD-2' pineapple was developed by D.F. Williams, T. Minagawa, and F. Bermudas at the Pineapple Research Institute of Hawaii (PRI). 'MD-2' resulted from a cross made in 1970 between PRI hybrids 58-1184 and 59-443. 'MD-2' was tested as selection number 73114 (Bartholomew, 2009). 'MD-2' has exceptional fruit quality with golden flesh color, high soluble solids, low acidity, and long postharvest life. The selection was released to both Maui Pineapple Company and the Del Monte Corporation (both members of PRI at the time) when PRI ceased pineapple breeding efforts in 1975. The 'MD-2' pineapple, currently grown and marketed by several companies worldwide, was never patented, although it was the subject of much legal dispute over the years. It has essentially displaced all other fresh pineapple production and is conservatively estimated to have annual sales of over $\$ 1$ billion (D. Bartholomew, personal communication).

\section{Red Raspberry}

'Autumn Bliss' Red Raspberry (2005) E. Keep and V. Knight. 'Autumn Bliss' was released by Elizabeth Keep and Vicky Knight at East Malling Research in East Malling, U.K., in 1984. 'Autumn Bliss' resulted from a cross of selection numbers $2806 / 36 \times 2335 /$ 47 and was tested as 3676/78 (Knight, 2002). 'Autumn Bliss' was released 11 years after the original cross, a record for the East Malling program. 'Autumn Bliss' was the first very early ripening primocane fruiting red raspberry with high fruit quality. 'Autumn Bliss' was unique in combining genes for primocane fruiting from three sources: 'Lloyd George', Rubus idaeus strigosus, and $R$. arcticus plus genes for firmness from $R$. occidentalis. 'Autumn Bliss' made primocane raspberry production a commercial reality and introduced raspberries as a new commercial crop to some regions with insufficient winter chilling to grow floricane raspberries. The fruit are fairly large, have a good, slightly dark color, a nice conic shape, and a pleasant favor with sufficient firmness to allow for shipping in the wholesale fruit market but susceptibility to
Raspberry bushy dwarf virus (RBDV) can cause the fruit to be crumbly. Quickly after its release, 'Autumn Bliss' became a standard for the industry and its greatest international impact has been as a parent in primocane breeding programs worldwide. Although current international sales are not known, over 100,000 plants were sold in the past five years for commercial fruit production in the Pacific Northwest (P. Moore, personal communication).

'Heritage' Red Raspberry (2004) G.L. Slate and D.K. Ourecky. 'Heritage' primocane fruiting red raspberry was selected in 1960 from a cross between New York 463 and 'Durham' and released in 1969 by D.K. Ourecky and G.L Slate from Cornell University's New York State Agricultural Experiment Station breeding program at Geneva (Daubeny et al., 1992). 'Heritage' is highyielding, reliably productive, has good fruit quality, and is firm enough to ship. In addition, it has some tolerance to Phytophthora root rot and RBDV. Before release of 'Heritage', primocane fruiting was more of a novelty, and 'Heritage' was the first primocane fruiting red raspberry that could be widely grown for wholesale shipping. The release of 'Heritage' started the rapid shift in the fresh wholesale market from floricane to primocane fruiting cultivars. By the early 1990s it was the world's predominant primocane fruiting cultivar. Today it is still an important cultivar; however, it has declined substantially in importance as cultivars that are brighter colored and that taste more like the summer fruiting cultivars have been developed. 'Heritage' has been a good parent with 'Caroline', 'Polana', 'Redwing', and 'Ruby' as direct offspring and has produced a number of yellow-fruited sports such as 'Kiwigold' and 'Graton Gold'.

'Meeker' Red Raspberry (1992) C.D. Schwartze. 'Meeker' was released by C.D. Schwartze at Washington State University in 1967 from a 1950 cross between 'Willamette' and 'Cuthbert'. It was selected in 1953 and tested as WSU 408. The name honors Ezra Meeker, a pioneer of the Puyallup Valley where the cultivar was selected and first tested (Moore and Daubeny, 1993). 'Meeker' has long clusters of fruit, tall canes, with long, strong, well-connected and well-spaced laterals. The fruit is late-ripening, large (for the time), conic, smooth and regular, coherent with drupelets of medium size, uniform, and medium firmness. The fruit is highly rated as a frozen product with good flavor, color, and shape retention. The combination of higher yields, more favorable fruit characteristics, and changes to harvesting machines allowed 'Meeker' to rapidly replace 'Willamette' in the late 1980 s as the leading cultivar in the Pacific Northwest, and it still comprises over $50 \%$ of the Pacific Northwest plant sales. In the past five years, almost 11 million plants of 'Meeker' have been sold in the Pacific Northwest for commercial fruit production. Although originally released for both fresh and processed uses, 'Meeker' currently is used almost exclusively for processing.
'Tulameen' Red Raspberry (2004) H.A. Daubeny. 'Tulameen', a floricane fruiting red raspberry from Canada's Pacific Agriculture Research Center (PARC) breeding program released by H.A. Daubeny, was selected from the 1980 cross of 'Nootka' $\times$ 'Glen Prosen'. 'Tulameen' was named in 1989, a remarkably short timespan for the development of a raspberry cultivar. 'Tulameen' is recognized for its bright glossy medium red-colored fruit with a quintessential raspberry flavor. The firm fruit texture results in good shelf life and suitability for long-distance transport. 'Tulameen' canes have relatively low chilling requirements and thus were suitable for early forcing under plastic tunnels, in greenhouses, and in open fields in Mediterraneantype climates. As a result, 'Tulameen' is widely planted in Europe, the Pacific Northwest of North America, in South America, particularly Chile, and in Australia and New Zealand. 'Tulameen' was one of the first raspberry cultivars to be sold by name. Notably, then Prime Minister Margaret Thatcher, while attending a "Summit" meeting in the United States, was served 'Tulameen' raspberries and enjoyed the berries so much she arranged for a flat to take back to Number 10 Downing Street in London. 'Tulameen' received a cultivar award from the Canadian Society for Horticultural Science in 2002 and in 2009 it received an Award of Merit from The Royal Horticultural Society in Britain, where after more than a decade, it is still considered the preferred cultivar for the premium range of most supermarkets.

\section{Strawberry}

'Camarosa' Strawberry (2002) V. Voth, R. Bringhurst, and D. Shaw. 'Camarosa' strawberry was released in 1993 by V. Voth, R. Bringhurst, and D. Shaw of the University of California, Davis and Irvine. 'Camarosa' resulted from a cross of 'Douglas' $\times \mathrm{Cal}$ 85.218-605 and was tested as selection number Cal 88.24-603. It replaced 'Chandler' with its higher yields and 2- to 3-d longer shelf life and became the industry standard in southern California. Short-day 'Camarosa' fruit are large, firm, and deep red; however, it is susceptible to anthracnose fruit rot (caused by Colletotrichum acutatum) and powdery mildew (caused by Sphaerotheca macularis). At its peak (1998-2000), 'Camarosa' contributed $70 \%$ of the strawberry fruit in the United States and over $50 \%$ worldwide. Its farm-gate value was $\$ 1.5$ billion.

'Cardinal' Strawberry (1990) J.N. Moore, H.L. Bowden, and W.A. Sistrunk. 'Cardinal' strawberry was developed at the University of Arkansas by J.N. Moore, H.L. Bowden, and W.A. Sistrunk. The University of Arkansas initiated their strawberry breeding program in 1964. Ark 5744 was identified from an 'Earlibelle' $\times$ Ark. 5063 cross made in 1967. The selection Ark 5744 was named 'Cardinal' and released in 1974. This June-bearing/shortday cultivar has wide adaptation in the lower Midwest, South, and upper South in the matted row system. It has very good fruit color 
along with firm berries. Likely the most novel characteristic is its broad adaptation. 'Cardinal' proved to be a very good parent in breeding in Arkansas and other programs. While widely planted in the lower Midwest and the South, it is not planted extensively outside of this region. This cultivar faded as annual plasticulture systems dominated by California-developed cultivars prospered and as anthracnose became a more serious problem.

'Chandler' Strawberry (1989) R.S. Bringhurst and V. Voth. 'Chandler' strawberry was introduced by R.S. Bringhurst and V. Voth of the University of California, Davis and Irvine, in 1983 from a 'Douglas' $\times$ Cal 72.361-105 (C55) cross. It dominated freshmarket production in southern California in the late 1980s and early 1990s as a result of its tender, juicy texture and exceptional flavor; however, it proved to be difficult to transport. Although still important in the southeastern United States, 'Chandler' was primarily replaced in California by 'Camarosa' as a result of its firmer texture and improved shipping characteristics. A lack of winterhardiness limits production of 'Chandler' to southern climates.

'Earliglow' Strawberry (1987) D.H. Scott, and A.D. Draper. 'Earliglow' strawberry resulted from a cross made in 1964 between 'Fairland' $X$ 'Midland' seedling with a 'Redglow' $\times$ 'Surecrop' seedling by D.H. Scott and A.D. Draper of the USDA-ARS Beltsville, MD, Fruit Laboratory. Seedlings were then screened for resistance to red stele root rot (Phytophthora fragariae) disease in 1964-65 and 'Earliglow' was selected as a resistant seedling in 1966. Released in 1975, 'Earliglow' quickly became the early-season standard in the eastern United States. 'Earliglow' has a fantastic, classic, full strawberry flavor. Although the primary berries are often large, the secondary and tertiary berries and the total yield are often smaller than desirable for commercial production. Nevertheless, 'Earliglow' remained an important cultivar in the 2000s as a result of its combination of outstanding traits.

\section{Walnut}

'Chandler' Walnut (1994) H. Forde and E. Serr. 'Chandler' walnut is a highly productive, laterally fruitful, midseason-harvested walnut. It was developed by H. Forde and E. Serr, founders of the University of California, Davis, walnut breeding program by crossing 'Pedro' and 56-224 in 1963. It was released in 1979 , and in 2008, 'Chandler' accounted for $41 \%$ of the walnut crop in California with $180,000 \mathrm{t}$ of product. 'Chandler' has good quality and very light-colored kernels that hold their color well. The nuts easily crack out in halves and store better than other cultivars. It is a standard large tree and not as susceptible to walnut blight as most other California cultivars.

\section{Literature Cited}

Ballington, J.R., C.M. Mainland, S.D. Duke, A.D. Draper, and G.J. Galletta. 1990. 'O'Neal' southern highbush blueberry. HortScience 25:711-712.

Bartholomew, D.P. 2009. 'MD-2' pineapple transforms the world's pineapple fresh fruit export industry. Pineapple News 16:2-5.

Beckman, T.G., G.L. Reighard, W.R. Okie, A.P. Nyczepir, E.I. Zehr, and W.C. Newall. 1997. History, current status and future potential of Guardian $^{\mathrm{TM}}$ (BY520-9) peach rootstock. Acta Hort. 451:251-258.

Crosby, J.A., J. Janick, P.C. Pecknold, J.C. Goffreda, and S.S. Korban. 1994. 'GoldRush' apple. 1994. HortScience 29:827-828.

Daubeny, H., K. Maloney, and G.R. McGregor. 1992. 'Heritage' red raspberry. Fruit Var. J. 46:2-3.

Dayton, D.F., J.B. Mowry, L.F. Hough, C.H. Bailey, E.B. Williams, J. Janick, and F.H. Emerson. 1970. Prima-An early fall red apple with resistance to apple scab. Fruit Var. Hort. Dig. 24:20-22.

Dokoozlian, N., D. Luvisi, M. Moriyama, and P. Schrader. 1995. Cultural practices improve color, size of 'Crimson Seedless'. Calif. Agr. 49:36-40.

Draper, A., G. Galletta, G. Jelenkovic, and N. Vorsa. 1987. 'Duke' highbush blueberry. HortScience 22:320.
Graham, C.J. 1999. 'Harvester' peach. Fruit Var. J. 53:130-132.

Hansen, M. 2012. Plum noted for its black skin. Good Fruit Grower 63:46.

Hearn, C.J. 1979. Performance of 'Sunburst', a new citrus hybrid. Proc. Fla. State Hort. Soc. 92:1-3.

Hutchison, D.J. 1974. Swingle citrumelo-A promising rootstock hybrid. Proc. Florida State Horticultural Society 87:89-91.

Janick, J. and J.N. Moore. 1974. Advances in fruit breeding. Purdue University Press, West Lafayette, IN

Knight, V.H. 2002. Raspberry breeding at HRIEast Malling. Acta Hort. 585:57-61.

Lyrene, P.M. and W.B. Sherman. 1992. The 'Sharpblue' southern highbush blueberry. Fruit Var. J. 46:194-196.

McCandless, L. 1996. Experiment station's successful Empire apple has its 30th birthday. Cornell Chronicle 28

Moore, J.N. and J.R. Clark. 2000. 'Navaho' blackberry. Fruit Var. J. 54:162-163.

Moore, J.N. and J. Janick. 1983. Methods in fruit breeding. Purdue University Press, West Lafayette, IN.

Moore, P.P. and H.A. Daubeny. 1993. 'Meeker red raspberry. Fruit Var. J. 47:2-4.

Nesbitt, W.B., D.E. Carroll, and V.H . Underwood. 1974. 'Noble' muscadine grape. HortScience 9:247.

Norton, R.A. 1989. World's best commercial dessert apples. Fruit Var. J. 43:102.

Okie, W.R. and S.C. Myers. 1991. 'Springcrest' peach. Fruit Var J. 45:190-192.

Ramming, D.W. 1991. Genetic control of a slowripening fruit trait in nectarine. Can. J. Plant Sci. 71:601-603.

Sherman, W.B., P.M. Lyrene, J.A. Mortensen, and R.H. Sharpe. 1982. 'Flordaprince' peach. HortScience 17:988.

Thompson, D., M. McCann, M. MacLeod, D. Lye, M. Green, and D. James. 2001. First report of Plum pox potyvirus in Ontario, Canada. Plant Dis. 85:97.

Thompson, T.E. and L.J. Grauke. 2000. 'Pawnee' pecan. J. Amer. Pom. Soc. 54:110-113.

Way, R.D. and S.K. Brown. 1991. 'Jonagold' apple. Fruit Var. J. 45:62-65.

Weinberger, J.H. 1970. Two new nectarines and a peach introduced by the U.S. Department of Agriculture. Fruit Var. Hort. Dig. 24:38-39.

Weinberger, J.H. and F.N. Harmon. 1974. 'Flame Seedless' grape. HortScience 9:602. 